\title{
A low molecular weight outer-membrane protein of Escherichia coli 0157:H7 associated with adherence to INT407 cells and chicken caeca
}

\author{
S. ZHAO, J. MENG, M. P. DOYLE, R. MEINERSMAN*, G. WANG and P. ZHAO \\ Center for Food Safety and Quality Enhancement and Department of Food Science and Technology, University \\ of Georgia, Griffin, GA 30223 and *Russell Research Center, USDA/ARS, Athens, GA 30613, USA
}

\begin{abstract}
Enterohaemorrhagic Escherichia coli (EHEC) 0157:H7 and 026:H11 have been shown to produce a low mol.wt outer-membrane protein (OMP) that is unique to a few serotypes of $E$. coli. A mutant (A10) of $E$. coli O157:H7 strain HA1 deficient in the OMP was constructed by $T$ nphoA mutagenesis and assayed for its adherent ability. Adherence of A10 to intestinal epithelial cells (INT407) was significantly less than that of its parent strain (HA1). Adherence of HA1 to INT407 cells was significantly decreased by treatment with a monoclonal antibody (4E8C12) that specifically binds to the OMP. When chickens were infected experimentally with $E$. coli $0157: H 7$ strains, the average number of cfu of strain A10 recovered from chicken caeca was significantly less than those of strain HA1 and wild-type strain 932 at 14 and 21 days after peroral inoculation. These data suggest that the OMP of EHEC is associated with adherence of E. coli 0157:H7 to epithelial cells in vitro and chicken caeca in vivo.
\end{abstract}

\section{Introduction}

Escherichia coli serotype $\mathrm{O} 157: \mathrm{H} 7$, a recognised cause of haemorrhagic colitis and haemolytic uraemic syndrome, is the principal serovar within the enterohaemorrhagic E. coli (EHEC) $[1,2]$. The organism can produce Shiga-like cytotoxins (SLT I or SLT II or both) that cause host cell death by inhibiting protein synthesis [1-3]. Also important to the pathogenicity of EHEC is its ability to attach to host cells [1,2]. However, the mechanism of E. coli $\mathrm{O} 157: \mathrm{H} 7$ adherence to host cells is poorly understood. Previous reports have suggested that outer-membrane proteins (OMP) rather than lipopolysaccharide (LPS) or flagella of E. coli $\mathrm{O} 157: \mathrm{H} 7$ play an important role in mediating binding of the bacteria to epithelial cells in vitro [4-6]. The mechanism of attachment of $E$. coli $0157: \mathrm{H} 7$ to intestinal mucosal cells has been studied extensively by several investigators [4-13]. Genes and their products that are involved in colonisation have been studied, but their exact roles, especially in the initial attachment of E. coli $\mathrm{O} 157: \mathrm{H} 7$, remain controversial and require further elucidation $[4,7,8,13,14]$.

Padhye and Doyle [15] produced a monoclonal antibody (MAb) 4E8C12 that reacts with a low mol.wt (originally described as $5-6 \mathrm{kDa}$, but deter-

Received 3 Oct. 1995; revised version accepted 7 Jan. 1996. Corresponding author: M. P. Doyle. mined to be $8 \mathrm{kDa}$ in the present study) OMP of EHEC O157:H7 and O26:H11. Because of the association of the OMP with EHEC [16], it was suggested that the OMP may be associated with the virulence of EHEC, perhaps associated with the organism's adherence. TnphoA mutagenesis allows the creation of mutants deficient in bacterial factors that normally are secreted or exported to the bacterial cell surface $[6,17,18]$. As all bacterial proteins implicated as virulence factors are extracellular or surface associated, TnphoA mutants can be used to identify genes that encode adherence factors $[5,18-$ 21]. Construction and analysis of EHEC TnphoA mutants can provide a foundation for the study of the molecular basis of the pathogenicity of EHEC. The objective of this study was to obtain a transposon Tn phoA mutant deficient in the low mol.wt OMP of EHEC, and to determine its ability to adhere to human intestinal epithelial cells (INT407) and chicken caeca.

\section{Materials and methods}

\section{Bacterial strains}

E. coli $\mathrm{O} 157: \mathrm{H} 7$ strain 932 was used as a positive control in the chicken inoculation study. E. coli O157:H7 strain HA1, derived from strain 932, was used as the recipient cell in conjugation studies. Strain HA1, which produces both SLT-I and SLT-II, was used for the development of MAb 4E8C12 for EHEC [15]. 
E. coli strain $\mathrm{SM}_{1}{ }_{\lambda}$ pir (thi thr leu tonA lacY supE rec $A:: \mathrm{RP} 4-2-\mathrm{Tc}:: \mathrm{Mu} \mathrm{Km}$ ) was the donor cell in conjugation studies with E. coli O157:H7 strain HA1, and was kindly provided by S. Craven (Russell Research Center, USDA/ARS, Athens, GA, USA). $\mathrm{SM} 10_{\lambda}$ pir carries a suicide plasmid pRT733 (oriR6K tra- mob- $\mathrm{Ap}^{r} \mathrm{Km}^{r}$ ) that bears transposon $\operatorname{Tn} p h o A$.

\section{Media and chemical reagents}

Luria broth (LB) and Luria plates were used for routine culturing of the bacteria, and MacConkey agar was used for enumeration. All media were obtained from Difco. Ampicillin (Ap, $100 \mu \mathrm{g} / \mathrm{ml})$, kanamycin $(\mathrm{Km}$, $45 \mu \mathrm{g} / \mathrm{ml}$ ), nalidixic acid (NA, $50 \mu \mathrm{g} / \mathrm{ml}$ ) and 5-bromo4-chloro-3-indolyl phosphate (XP, $40 \mu \mathrm{g} / \mathrm{ml})$ were added when appropriate. All chemical reagents were purchased from Sigma.

\section{Construction of TnphoA mutants}

A NA $(50 \mu \mathrm{g} / \mathrm{ml})$-resistant strain of HAl was obtained by plating on to MacConkey agar plates containing different concentrations $(1-50 \mu \mathrm{g} / \mathrm{ml})$ of NA. Transposon $\operatorname{Tn} p h o A$ from suicide plasmid vector pRT733 was introduced into the NA-resistant $\mathrm{HAl}$ by plate matings with the donor cell $\mathrm{SM}_{10}$ pir. In-frame transposon insertion into signal-sequence containing genes resulted in phenotypes of $\mathrm{Tn}$ phoA mutants that were $\mathrm{Km}^{r}$, $\mathrm{NA}^{r}$ and formed blue colonies on LB plates containing $\mathrm{Km}$, NA and XP (an indicator dye for alkaline phosphatase activity).

\section{Screening TnphoA mutants by immunodot-blot assay}

Approximately $800 \mathrm{Km}^{r}$, $\mathrm{NA}^{r}$ blue colonies were selected from separate conjugation experiments for immunodot-blot screening. The immunodot-blot assay was performed by the following procedure. Briefly, an Immobilon-PVDF membrane (Millipore Corp., Bedford, MA, USA) was cut $(8 \times 12 \mathrm{~cm})$, soaked in $10 \mathrm{ml}$ of methanol $100 \%$ for $2 \mathrm{~s}$, and placed in coating buffer (0.05 $\mathrm{M}$ carbonate buffer, $\mathrm{pH} 9.6)$ for $10 \mathrm{~min}$ before use. The Tn phoA mutants were grown in $5 \mathrm{ml}$ of LB containing $\mathrm{Km}$ and NA for $18 \mathrm{~h}$ at $37^{\circ} \mathrm{C}$. Fifty $\mu 1(c$. $10^{8} \mathrm{cfu}$ ) of each broth culture were placed on to the membrane assembled in a dot-blot manifold (BRL, Gaithersburg, MD, USA). The membrane was air dried for $5 \mathrm{~min}$ after blotting the cultures, and then submerged in bovine serum albumin (BSA) $5 \% \mathrm{w} / \mathrm{v}$

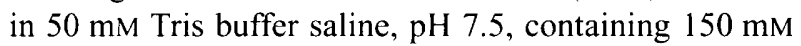
$\mathrm{NaCl}$ with Tween-20 $0.05 \% \mathrm{v} / \mathrm{v}$ (TBS-T) plus sodium azide $0.05 \% \quad \mathrm{w} / \mathrm{v}$ at $37^{\circ} \mathrm{C}$ for $1 \mathrm{~h}$ with agitation $(100 \mathrm{rpm})$. The membrane was soaked in $20 \mathrm{ml}$ of MAb 4E8C12 (ascites fluid diluted 1 in 400 in TBS-T) for $1 \mathrm{~h}$ at room temperature, washed three times with TBS-T for $10 \mathrm{~min}$ each, and then incubated with alkaline phosphatase-labelled goat anti-mouse IgG (diluted at 1 in 800 in TBS) for $30 \mathrm{~min}$ at $37^{\circ} \mathrm{C}$. The membrane was washed four times, and placed in a substrate of 5-bromo-4-chloro-3-indolyl phosphate/ nitroblue tetrazolium (BCIP/NBT) (Kirkegard and Perry Laboratory, Inc., Gaithersburg, MD, USA) for $1 \mathrm{~min}$ at room temperature. The reaction was stopped by rinsing the membrane with distilled water for $1 \mathrm{~min}$. A dark purple spot and a light purple spot indicated positive and negative reactions with $\mathrm{MAb} 4 \mathrm{E} 8 \mathrm{C} 12$, respectively. E. coli $\mathrm{O} 157: \mathrm{H} 7 \mathrm{HA} 1$ and $\mathrm{SM}_{10}$ pir served as positive and negative controls, respectively.

\section{Tricine-SDS-PAGE and Western blot analysis}

The TnphoA mutant, designated as A10 that gave a negative result in immunodot-blot assay, was selected for Tricine-SDS-PAGE and Western blot analysis to confirm that it did not express the low mol.wt OMP. The OMP of strains $\mathrm{A} 10, \mathrm{HAl}$ and $\mathrm{SM} 10_{\lambda}$ pir were extracted by the method of Hjelmeland and Chrambach [22]. Tricine-SDS-PAGE was performed following the procedures described by Schargger and van Jagow [23];

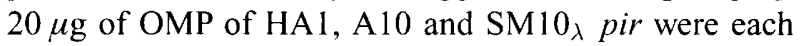
loaded on gels consisting of a separating $20 \%$ gel, a spacer $10 \%$ gel and a stacking $4 \%$ gel in a double-slab electrophoresis unit (Protean; BioRad Laboratories, Richmond, CA, USA) and run at constant $90 \mathrm{~mA}$ for $7 \mathrm{~h}$. Low range mol. wt markers (Sigma) were included on the gels. Protein bands were visualised by staining with Coomassie Blue $2.5 \% \mathrm{w} / \mathrm{v}$ for $2 \mathrm{~h}$ and destaining in methanol $40 \% \mathrm{v} / \mathrm{v}$ and acetic acid $20 \% \mathrm{v} / \mathrm{v}$. Western blotting was performed according to the procedure described by Padhye and Doyle [15]. After electrophoresis, proteins were transferred to a PVDF membrane in a buffer containing $25 \mathrm{mM}$ Tris- $\mathrm{HCl}(\mathrm{pH} 8.3)$, $192 \mathrm{mM}$ glycine, methanol $20 \% \mathrm{v} / \mathrm{v}$ and SDS $0.05 \%$ $\mathrm{w} / \mathrm{v}$ in a transblot apparatus (Multiphor II; Pharmacia, Piscataway, NJ, USA) at $400 \mathrm{~mA}$ for $40 \mathrm{~min}$. The procedures for immunostaining were the same as the dot-blot immunoassay described above, except that MAb 4E8C12 was diluted 1 in 1600 and goat antimouse antibody was diluted 1 in 2000 in TBS-T.

\section{Southern blot hybridisation}

The genomic and plasmid DNA of strain A10 were extracted by a mini-preparation procedure $[24,25]$. For each DNA preparation, $2 \mu \mathrm{g}$ were digested at $37^{\circ} \mathrm{C}$ for $3 \mathrm{~h}$ with restriction endonuclease EcoRV (BRL) that does not cleave within TnphoA. The DNA fragments were separated by electrophoresis in agarose $0.8 \% \mathrm{w} / \mathrm{v}$ gel and transferred on to a Nylon membrane (Sigma). The genomic DNA of strain HAl was also isolated and subjected to Southern hybridisation to serve as a control. The plasmid DNA of pRT733 was extracted by mini-preparation, digested with restriction endonuclease $B g l \mathrm{II}$, and separated in agarose $0.8 \% \mathrm{w} / \mathrm{v}$ gel. A $2.8-\mathrm{kbp} B g l \mathrm{II}$ fragment that contains the $\mathrm{Km}$ resistance gene found in $\operatorname{Tn} p h o A$ was isolated from the gel, purified by GeneClean II (Bio 101, La Jolla, CA, USA), and labelled with $\alpha-{ }^{32} \mathrm{P}$ dATP by the 
random-primer method [26], to serve as the probe for Southern hybridisation. Lambda DNA digested with HindIII was also labelled with $\alpha-{ }^{32} \mathrm{P}$ dATP and included in hybridisation experiments as a molecular marker. The hybridisation was performed in a solution containing formamide $50 \%, 6 \times \mathrm{SSC}(0.9 \mathrm{M} \mathrm{NaCl}$, $0.09 \mathrm{M}$ sodium citrate, $\mathrm{pH} 7.0)$, SDS $0.5 \% \mathrm{w} / \mathrm{v}$, $5 \times$ Denhardt's solution (Ficoll $0.1 \%$, polyvinypyrrollidone $0.1 \%$, BSA $0.1 \%$ ) and single strand DNA $100 \mu \mathrm{g} /$ $\mathrm{ml}$, for $16 \mathrm{~h}$ at $42^{\circ} \mathrm{C}$.

\section{Adherence assay}

INT407 cells were obtained from the American Type Culture Collection (Rockville, MD, USA). The cells were grown in Basal Medium Eagle (BME) plus fetal bovine serum (FBS; BRL) $15 \%$. The adherence assay was performed by the method of Junkins and Doyle with minor modification [27]. Briefly, INT407 cells were inoculated into each well $(35 \mathrm{~mm}$ in diameter) of a six-well tissue culture plate with lid (Corning Glass Works, Corning, NY, USA) at a concentration of $10^{5}$ $10^{6}$ viable cells, and grown in BME plus FBS $15 \%$ at $37^{\circ} \mathrm{C}$ until confluent (2-3 days). Overnight bacterial cultures were sedimented by centrifugation $(16000 \mathrm{~g}$, $1 \mathrm{~min}$ ) and resuspended to an $\mathrm{OD}_{640 \mathrm{~nm}}$ of 0.5 with TBS ( $50 \mathrm{mM}$ Tris- $\mathrm{HCl}, 150 \mathrm{mM} \mathrm{NaCl}, \mathrm{pH} 7.4$ ) plus $10 \mu \mathrm{M}$ $\mathrm{ZnCl}_{2}$. The bacterial suspension $(2 \mathrm{ml})$ was applied to an INT407 monolayer and incubated at $37^{\circ} \mathrm{C}$ for $2 \mathrm{~h}$ without agitation. After incubation, the suspension was removed from the monolayer, and non-adherent bacterial cells were removed by rinsing five times with $3 \mathrm{ml}$ of TBS plus $10 \mu \mathrm{M} \mathrm{ZnCl}_{2}$ plus Tween $200.1 \% \mathrm{v} / \mathrm{v}$. The monolayer was then treated with $2 \mathrm{ml}$ of $2 \mathrm{mM}$ $\mathrm{Na}_{2}$ EDTA in TBS for $1 \mathrm{~min}$. The bacteria were separated from INT407 cells by vortex mixing. The number of viable bacteria in the suspension was determined by plating serial ( 1 in 10 ) dilutions of the suspension on MacConkey agar plates, followed by overnight incubation at $37^{\circ} \mathrm{C}$. The number of INT407 cells in the suspension was determined by haemocytometry. The number of adherent bacteria/INT407 cells was then calculated. To minimise experimental error, positive (HA1) and negative (SM10 $0_{\lambda}$ pir) controls were always included in each tissue culture plate.

\section{Adherence inhibition assay}

Six adherence inhibition assays also were performed. The procedures of the adherence inhibition assay were the same as those of the adherence assay except that $E$. coli $\mathrm{O} 157: \mathrm{H} 7$ strain $\mathrm{HAl}$ was treated with $\mathrm{MAb}$ $4 \mathrm{E} 8 \mathrm{C} 12$ (ascites fluid) before being added to the INT407 monolayer. The MAb (diluted 1 in 200 and 1 in 400) was added to $2 \mathrm{ml}$ of bacterial suspension and incubated at $37^{\circ} \mathrm{C}$ for $1.5 \mathrm{~h}$. Strains $\mathrm{A} 10$ and $\mathrm{HAl}$ that were not treated with MAb served as controls in each test. Data of the adherence and adherence-inhibition assays were analysed statistically by the $t$-test [28].

\section{Chicken colonisation study}

The methods used for the chicken colonisation study were described previously [29]. Briefly, E. coli O157:H7 strains 932, HAl and mutant A10 were cultured at $37^{\circ} \mathrm{C}$ in Trypticase Soy Broth (TBS; BBL Microbiology System, Cockeysville, MD, USA) with appropriate chemicals for $24 \mathrm{~h}$. Cells were washed three times and resuspended in $0.01 \mathrm{M}$ phosphatebuffered saline (PBS) pH 7.5. Two trials of the chicken inoculation study were conducted (Table 1). In trial I, 105 1-day-old chicks (Peterson/Arbor-Acre) were divided into four groups, of which 15 chicks served as controls and received $0.25 \mathrm{ml}$ of PBS perorally into the crop via a $1-\mathrm{ml}$ syringe, and the remaining 90 chicks received $c .10^{9} \mathrm{cfu}$ of $E$. coli $(30 \mathrm{chicks} / \mathrm{strain})$ by the same procedure. Five chicks from the control and 10 chicks from each test group were killed at 7, 14 and 21 days post-inoculation for bacterial enumeration. In trial II, two more sampling times ( 3 and 5 days) were added (Table 1).

Immediately after they were killed, the internal organs of chicks were dissected and caeca were removed aseptically and placed in plastic sterile tubes. The tissue was weighed, diluted ( 1 in 10) in cold PBS and

Table 1. Recovery of E. coli $\mathrm{O} 157: \mathrm{H} 7$ strains from chicken caeca after peroral inoculation

\begin{tabular}{|c|c|c|c|c|c|}
\hline \multirow{2}{*}{$\begin{array}{l}\text { Strain } \\
\text { no. }\end{array}$} & \multicolumn{5}{|c|}{ E. coli $\log _{10} \mathrm{cfu} / \mathrm{g}$ of caecal tissue and contents (SD) at post-inoculation times } \\
\hline & 3 days & 5 days & 7 days & 14 days & 21 days \\
\hline \multicolumn{6}{|l|}{ Trial I } \\
\hline 932 & $\cdots$ & $\ldots$ & $3.68(0.82)$ & $4.81(1.3)$ & $3.75(0.86)$ \\
\hline HA1 & $\ldots$ &.- & $2.36(1.85)$ & $3.50(0.68)$ & $4.04(0.33)$ \\
\hline A 10 & -- & -- & $1.6(1.79)^{*}$ & $<1.0 \dagger$ & $<1.0^{\dagger}$ \\
\hline \multicolumn{6}{|l|}{ Trial II } \\
\hline 932 & $4.65(0.78)$ & $5.37(0.93)$ & $5.38(1.54)$ & $6.11(1.24)$ & $3.99(1.30)$ \\
\hline HAl & $4.05(0.88)$ & $3.30(0.89)$ & $3.17(0.61)$ & $3.54(1.99)$ & $4.02(1.60)$ \\
\hline $\mathrm{A} 10$ & $5.89(0.90)$ & $5.40(0.94)$ & $4.06(0.91)$ & $2.15(1.98) \ddagger$ & $2.34(2.51)^{*}$ \\
\hline
\end{tabular}

${ }^{*}$ Strain A10 ( $<10 \mathrm{cfu} / \mathrm{g}$ of caeca; minimum level of sensitivity $)$ detected in five of 10 chicks.

$\dagger$ Strain A10 $(<10 \mathrm{cfu} / \mathrm{g})$ detected in 10 chicks.

$\$$ Strain A10 $(<10 \mathrm{cfu} / \mathrm{g})$ detected in four of 10 chicks. 
homogenised aseptically for $1 \mathrm{~min}$ with a Polytron tissue homogeniser (Brinkman Industries, Inc., Weatbury, NJ, USA). Samples were serially diluted ( 1 in 10 ) in PBS, and each dilution was plated in duplicate on sorbitol-MacConkey agar containing nalidixic acid $30 \mu \mathrm{g} / \mathrm{ml}$. For enumeration of the mutant $\mathrm{A} 10$, kanamycin $40 \mu \mathrm{g} / \mathrm{ml}$ also was added to the medium. The plates were incubated at $37^{\circ} \mathrm{C}$ for $48 \mathrm{~h}$, and colonies typical of $E$. coli were counted. At least one typical $E$. coli colony from a plate at the highest dilution of tissue was confirmed serologically as $E$. coli $\mathrm{O} 157$ by latex agglutination with O157-specific antiserum (Unipath, Basingstoke). Data of the chicken study were analysed statistically by the $t$-test [28].

\section{Results}

Construction of low mol.wt OMP-deficient mutants of E. coli O157:H7

Approximately $800 \mathrm{Km}^{r}$, $\mathrm{NA}^{r}$ blue colonies were selected from hundreds of separate conjugation experiments for immunodot-blot screening. A mutant, designated A10, did not react with $\mathrm{MAb} 4 \mathrm{E} 8 \mathrm{C} 12$ in the dot blot assay. Strain A10 retained many of the characteristics of its parent strain, HAl, such as production of SLT I and SLT II, agglutination with O157 polyclonal antiserum, genomic DNA profile by pulsed-field gel electrophoresis and inability to hydrolyse $\quad 4$-methylumbelliferyl $\quad \beta$-D-glucuronide (MUG), except that Al0 was $\mathrm{Km}^{r}$, obtained from Tn $p h o A$.

\section{OMP analysis}

Tricine-SDS-PAGE and Western blotting were performed to analyse the OMP of mutant A10, the parent stain HA1 and donor strain SM10. The tricine-SDSPAGE profiles indicated that one band representing the c. $8-\mathrm{kDa}$ OMP that was present in strain HAl was missing from strain A10. The OMP profile of $\mathrm{SM}_{10}$ pir was very different from those of strain $\mathrm{HAl}$ and A10 (Fig. 1A). Western immunoblot analysis of the OMP revealed that the HAl OMP reacted with $\mathrm{MAb}$ $4 \mathrm{E} 8 \mathrm{C} 12$, whereas those of strains $\mathrm{A} 10$ and $\mathrm{SM} 10_{\lambda}$ pir did not (Fig. 1B), further confirming that strain A10 was deficient in the low mol.wt OMP.

\section{Genetic analysis}

Hybridisation of genomic and plasmid DNA of strain A10 with the $2.8-\mathrm{kbp} \mathrm{Km}^{r}$ gene probe showed that A10 contained a single TnphoA insertion located on the chromosomal DNA, and that the plasmid DNA of strain A10 had no $\operatorname{Tn} p h o A$ insertion (Fig. 2). The hybridised EcoRV fragment of A10 genomic DNA, which contained TnphoA flanking the target gene, was c. $9.4 \mathrm{~kb}$ (Fig. 2). The genomic DNA of strain HAl did not hybridise with the probe (data not shown).
A

B

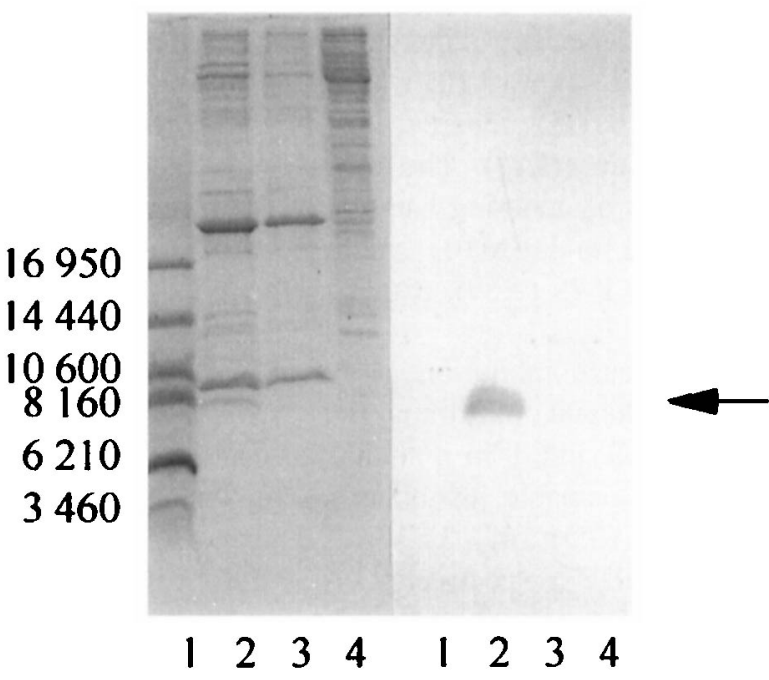

Fig. 1. Tricine-SDS-PAGE Coomassie Blue staining pattern (A) and Western blot (B) of OMPs of E. coli O157:H7 strain HAl (lane 2), E. coli O157:H7 mutant strain A10 (3), E. coli strain SM10 ${ }_{\lambda}$ pir (4);20 $\mu \mathrm{g}$ of OMP was loaded in each lane and the low mol.wt markers $(\mathrm{Da})$ were applied in lane 1 . The arrow indicates the position of the low mol.wt OMP recognised specifically by $\mathrm{MAb} 4 \mathrm{E} 8 \mathrm{C} 12$.

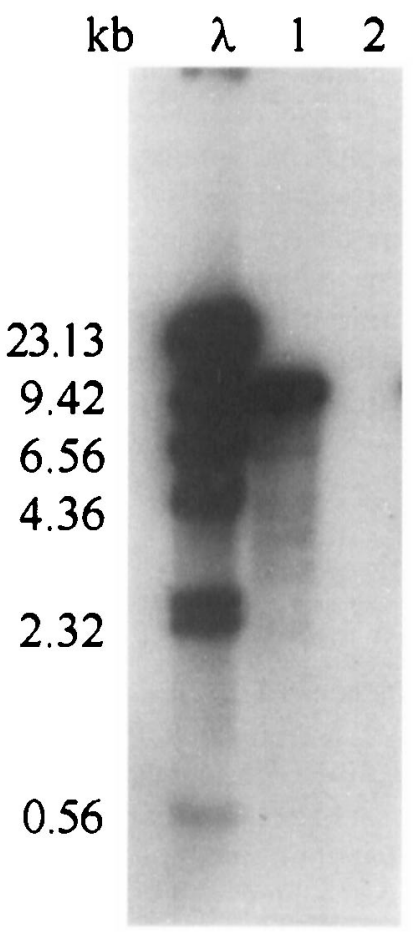

Fig. 2. Southern blot hybridisation of genomic (lane 1) and plasmid (2) DNA of E. coli $0157: \mathrm{H} 7$ mutant strain A10, digested with EcoRV and hybridised with a mixture of $\alpha{ }^{32} \mathrm{P}$ dATP-labelled $2.8-\mathrm{kb} \quad B g l$ II fragment of Tn pho $A$ and $\alpha{ }_{-}{ }^{32} \mathrm{P}$ dATP-labelled HindIII-digested lambda DNA. 


\section{Adherence assay}

Fifteen independent adherence assays were performed. The mutant strain (A10) was shown to be significantly less $(p<0.005$ ) adherent to INT407 cells than the parent strain (HA1). The means and standard deviations (SD) of adhering bacteria/INT407 cell for strains A10, HAl and $\mathrm{SM}_{10}$ pir were $1.62(0.97), 133.1$ (6.17) and 2.75 (2.69), respectively.

Six adherence inhibition assays also were performed. After treatment of strain $\mathrm{HAl}$ with $\mathrm{MAb} 4 \mathrm{E} 8 \mathrm{C} 12$ at 1 in 200 and 1 in 400 dilutions at $37^{\circ} \mathrm{C}$ for $1.5 \mathrm{~h}$, HA1 was capable of adhering to INT407 cells at a mean (SD) of 3.53 (2.51) and 2.52 (2.17) bacteria/cell, respectively. As the controls, the means (SD) of adhering bacteria/INT407 cells for strains A10 and HAl were $0.93(0.49)$ and 9.49 (3.91), respectively. Results with and without treatments with $\mathrm{MAb} 4 \mathrm{E} 8 \mathrm{C} 12$ indicate that $\mathrm{MAb}$ 4E8C12 significantly $(\mathrm{p}<0.05)$ inhibited adherence of strain HA1 to INT407 cells. If strain HAl was treated with the MAb at the 1 in 1600 dilution and held at $37^{\circ} \mathrm{C}$ for $1.5 \mathrm{~h}$, the ability of HA1 to adhere to INT407 cells was not significantly $(p>0.05)$ different from that of bacteria that were not treated with the MAb.

\section{Chicken colonisation study}

Results of caecal colonisation with E. coli $\mathrm{O} 157: \mathrm{H} 7$ strains 932, HAl and OMP-mutant Al0 in chickens after peroral inoculation are shown in Table 1. In trial I, strain A10 was not isolated at 14 and 21 days after peroral inoculation, whereas strains 932 and HAl were still present in the caeca at levels $>10^{3} \mathrm{cfu} / \mathrm{g}$ of caeca. Similar results were observed in trial II, in which strain A10 was not recovered after 14 and 21 days postinoculation in at least four of 10 chicks. The average number of cfu of strain A10 recovered from caeca was significantly less $(p<0.05)$ than those of strains 932 and HA1.

\section{Discussion}

Factors involving E. coli $\mathrm{O} 157: \mathrm{H} 7$ adhesion and attaching and effacing (A-E) lesion formation have been studied by several investigators $[4-12,30]$. Donnenberg et al. [4] reported that the eae gene is necessary for intimate attachment of EHEC in vivo, but the precise role of intimin, the product of the eae gene of EHEC, in the attaching and effacing phenomena is unknown [4]. Sherman et al. [9] suggested that a 94-kDa OMP was intimin because antiserum raised to this OMP blocked adhesion and F-actin lesion formation of $E$. coli $\mathrm{O} 157: \mathrm{H} 7$ strain CL56 on tissue culture cells. In later studies, Louie et al. [8] determined by peptide sequencing, immunoassay and expression of the carboxyl-terminal 266 amino acid of intimin of $E$. coli $\mathrm{O} 157: \mathrm{H} 7$ strain CL8, that intimin was a $97-\mathrm{kDa}$ OMP and was different from the $94-\mathrm{kDa}$ OMP.

Dytoc et al. [5] determined that E. coli HB101 transformed with the cloned EHEC eae gene did not form attaching and effacing lesions on cultured epithelial cells in vitro or rabbit intestinal tissue in vivo. Louie et al. [8] determined that an eae insertional inactivation mutant of strain CL-8 (CL8$\mathrm{K} 01)$ gave negative results in the fluorescent actin staining (FAS) test, but adherence of CL8-K01 to HEp-2 cells was not significantly different from that of CL8. Furthermore, the eae gene expressed alone in E. coli HB101 did not significantly increase adherence to HEp-2 cells compared with the parent HB101, despite the fact that $E$. coli $\mathrm{O} 157: \mathrm{H} 7$ intimin was localised in the outer membrane and was surface exposed. They concluded that intimin contributes minimally if at all to the total adherence of strain CL8 to HEp-2 cells. Dytoc et al. [5] used TnphoA mutagenesis to identify factors that were necessary for O157:H7 A-E lesion formation and were not likely to be an eae gene product in two TnphoA mutants. Recently, Leroy et al. [31] reported the presence of the eae gene in non-pathogenic $E$. coli strains isolated from rabbits. Hence, it appears that production of A-E lesions by EHEC depends on the expression of several genes and these are affected by environmental conditions. Adherence of EHEC to epithelial cells still occurs without the eae gene. Furthermore, introduction of the eae gene into other non-adherent $E$. coli strains does not necessarily result in their ability to adhere to epithelial cells because other essential factors are missing.

Recent studies have revealed that a large $(35 \mathrm{~kb})$ region in the enteropathogenic $E$. coli (EPEC) chromosome, locus of enterocyte effacement (LEE), containing eaeA, eaeB, $\operatorname{sep} A, \operatorname{sep} B, \operatorname{sep} C$ and $\operatorname{sep} D$ (sep, for secretion of $E$. coli proteins), encodes the virulence determinants for A-E lesion formation of EPEC that have been identified to date $[32,33]$. This region is conserved among other pathogens that produce the A-E lesion, including E. coli $\mathrm{O} 157: \mathrm{H7}$, and is inserted into the $E$. coli chromosome at the identical site where a block of virulence genes or 'pathogenicity island' of uropathogenic E. coli is located [32]. Therefore, more studies are needed to determine the precise role of intimin, other adherence factors, the host cell receptor and their interactions in the process of colonisation.

Although E. coli $\mathrm{O} 157: \mathrm{H} 7$ has not been isolated from chickens, this organism is able to colonisè well in chickens, caeca being the primary site of colonisation [29]. In the present study, chickens were used to evaluate the effect of the low mol.wt OMP on the colonisation of $E$. coli $\mathrm{O} 157: \mathrm{H} 7$ in vivo. The mutant deficient in the OMP had significantly reduced ability 
to colonise chicken caeca compared to the parent strain of E. coli $\mathrm{O} 157: \mathrm{H} 7$.

Recent studies in this laboratory indicate that the OMP has a close association with the lipid A portion of LPS on the cell membrane of E. coli $0157: \mathrm{H} 7$, similar to the association of LPS and outer-membrane proteins in other $E$. coli $[34,35]$. E. coli $\mathrm{O} 157: \mathrm{H} 7$ strain HAl was obtained while attempting to isolate a variant of E. coli $\mathrm{O} 157: \mathrm{H} 7$ strain 932 that was highly adherent to Henle 407 cell monolayers [15]. Strain 932 was passaged several times on Henle 407 cell monolayers. Each time only those bacteria that remained attached to the monolayers after washing were cultured. Strain HAl was isolated from passage 11 and was highly adherent to Henle 407 cells. This strain lacks a portion of the LPS layer of the cell outer membrane, allowing greater exposure of the unique low mol.wt OMP than its parent strain and other wild-type strains of E. coli O157:H7. The OMP also is expressed in greater amounts when bile salts and acriflavine are present in the growth medium [16]. Interestingly, Bilge et al. [36] reported that E. coli O157:H7 LPS-mutants were hyperadherent. Their studies suggested that the increased ability of the O157-mutants to adhere to HeLa cells could result from increased contact between the bacterial adhesin and the epithelial cell surface in the absence of $O$ side chains. It appears that the environment of the intestinal tract of animals and man could influence eae genes and other factors, including expression of the OMP, in their involvement in the process of colonisation. In conclusion, the low mol.wt OMP is associated with the adherence of $E$. coli $\mathrm{O} 157: \mathrm{H} 7$ to cultured human epithelial cells and chicken caeca, and the mechanism of this involvement remains to be determined.

We thank Tong Zhao for technical assistance. This study was supported in part by USDA Special Grant 93-COOP-2-9591, USDA NRI 94-37201-1-67.

\section{References}

1. Griffin PM, Tauxe RV. The epidemiology of infections caused by Escherichia coli $0157: \mathrm{H} 7$, other enterohemorrhagic $E$. coli, and the associated hemolytic uremic syndrome. Epidemiol Rev 1991; 13: 60-98.

2. Padhye NV, Doyle MP. Escherichia coli O157:H7: epidemiology, pathogenesis, and methods for detection in food. $J$ Food Prot 1992; 55: 555-565.

3. O'Brien AD, Holmes RK. Shiga and Shiga-like toxins. Microbiol Rev 1987; 51: 206-220.

4. Donnenberg MS, Tzipori S, McKee ML, O'Brien AD, Alroy J, Kaper JB. The role of the eae gene of enterohemorrhagic Escherichia coli in intimate attachment in vitro and in a porcine model. J Clin Invest 1993; 92: 1418-1224.

5. Dytoc M, Soni R, Cockerill F et al. Multiple determinants of verotoxin-producing Escherichia coli O157:H7 attachmenteffacement. Infect Immun 1993; 61: 3382-3391.

6. Sherman P, Soni R. Adherence of verocytotoxin-producing Escherichia coli of serotype O157:H7 to human epithelial cells in tissue culture: role of outer membranes as bacterial adhesins. J Med Microbiol 1988; 26: 11-17.
7. Karch H, Heesemann J, Laufs R, O'Brien AD, Tacket CO, Levine MM. A plasmid of enterohemorrhagic Escherichia coli $\mathrm{O} 157: \mathrm{H} 7$ is required for expression of a new fimbrial antigen and for adhesion to epithelial cells. Infect Immun 1987; 55: $455-461$.

8. Louie M, De Azavedo JCS, Handelsman MYC et al. Expression and characterization of the eaeA gene product of Escherichia coli serotype O157:H7. Infect Immun 1993; 61: 4085-4092.

9. Sherman P, Cockerill F, Soni R, Brunton J. Outer membranes are competitive inhibitors of Escherichia coli 0157:H7 adherence to epithelial cells. Infect Immun 1991; 59: 890-899.

10. Toth I, Cohen ML, Rumschlag HS et al. Influence of the 60megadalton plasmid on adherence of Escherichia coli 0157$\mathrm{H} 7$ and genetic derivatives. Infect Immun 1990; 58: 12231231.

11. Tzipori S, Gibson R, Montanaro J. Nature and distribution of mucosal lesions associated with enteropathogenic and enterohemorrhagic Escherichia coli in piglets and the role of plasmid-mediated factors. Infect Immun 1989; 57: 1142-1150.

12. Tzipori S, Karch H, Wachsmuth $\mathrm{KI}$ et al. Role of a 60megadalton plasmid and Shiga-like toxins in the pathogenesis of infection caused by enterohemorrhagic Escherichia coli O157-H7 in gnotobiotic piglets. Infect Immun 1987; 55: 31173125.

13. Beebakhee G, Louie M, De Azavedo J, Brunton J. Cloning and nucleotide sequence of the eae gene homologue from enterohemorrhagic Escherichia coli serotype O157:H7. FEMS Microbiol Lett 1992; 91: 63-68.

14. Yu J, Kaper JB. Cloning and characterization of the eae gene of enterohemorrhagic Escherichia coli O157:H7. Mol Microbiol 1992; 6: 411-417.

15. Padhye NV, Doyle MP. Production and characterization of a monoclonal antibody specific for enterohemorrhagic Escherichia coli of serotypes $\mathrm{O} 157: \mathrm{H} 7$ and $\mathrm{O} 26: \mathrm{H} 11 . J$ Clin Microbiol 1991; 29: 99-103.

16. Clark CG, Johnson S, Johnson RP. Further characterisation of a monoclonal antibody reactive with Escherichia coli O157:H7. J Med Microbiol 1995; 43: 262-269.

17. Hoffman CS, Wright A. Fusion of secreted proteins to alkaline phosphatase: an approach for studying protein secretion. Proc Natl Acad Sci USA 1985; 82: 5107-5111.

18. Manoil C, Beckwith J. TnphoA: A transposon probe for protein export signals. Proc Natl Acad Sci USA 1985; 82: 8129-8133.

19. Donnenberg MS, Calderwood SB, Donohue-Rolfe A, Keusch GT, Kaper JB. Construction and analysis of TnphoA mutants of enteropathogenic Escherichia coli unable to invade HEp-2 cells. Infect Immun 1990; 58: 1565-1571.

20. Jerse AE, Kaper JB. The eae gene of enteropathogenic Escherichia coli encodes a 94-kilodalton membrane protein, the expression of which is influenced by EAF plasmid. Infect Immun 1991; 59: 4302-4309.

21. Taylor RK, Manoil C, Mekalanos JJ. Broad-host-range vectors for delivery of TnphoA: use in genetic analysis of secreted virulence determinants of Vibrio cholerae. J Bacteriol 1989; 171: $1870-1878$

22. Hjelmland LM, Chrambach A. Solubilization of functional membrane-bound receptors. In: Venter JC, Harrison LC (eds) Membrane, detergents and receptors solubilization. New York, Alan R. Liss. 1984: 35-46.

23. Schagger $H$, van Jagow $G$. Tricine-sodium dodecyl sulfatepolyacrylamide gel electrophoresis for the separation of proteins in the range from 1-100 kDa. Anal Biochem 1987; 166: $368-379$.

24. Lech K, Brent R. Minipreps of plasmid DNA. In: Ausubel FM, Brent R, Kingston RE et al. (eds) Short protocols in molecular biology - a compendium of methods from Current Protocols in Molecular Biology. New York, John Wiley and Sons. 1989: 19-20.

25. Wilson K. Preparation of genomic DNA from bacteria. In: Ausubel FM, Brent R, Kingston RE et al. (eds) Short protocols in molecular biology - a compendium of methods from Current Protocols in Molecular Biology. New York, John Wiley and Sons. 1989: 61-63.

26. Feinberg AP, Vogelstein B. A technique for radiolabeling DNA restriction endonuclease fragments to high specific activity. Anal Biochem 1983; 132: 6-13.

27. Junkins AD, Doyle MP. Comparison of adherence properties of 
Escherichia coli $0157: \mathrm{H} 7$ and a 60-megadalton plasmid-cured derivative. Curr Microbiol 1989; 19: 21-27.

28. Daniel WW. Hypothesis testing. In: Daniel WW (ed) Biostatistics: a foundation for analysis in the health sciences. New York, John Wiley and Sons. 1987: 188-272.

29. Berry JT, Doyle MP, Schoeni JL. Colonization of chicken cecae by Escherichia coli associated with hemorrhagic colitis. Appl Environ Microbiol 1985; 49: 310-315.

30. Ashkenazi S, May L, LaRocco M, Lopez EL, Cleary TG. The effect of postnatal age on the adherence of enterohemorrhagic Escherichia coli to rabbit intestinal cells. Pediatr Res 1991; 29: 14-19.

31. Leroy SM, Lesage M-C, Chaslus-Dancla E, Lafont JP. Presence of eaeA sequences in pathogenic and non-pathogenic Escherichia coli strains isolated from weaned rabbits. $J$ Med Microbiol 1994; 40: 90-94.

32. McDaniel TK, Jarvis $\mathrm{KG}$, Donnenberg MS, Kaper JB. A genetic locus of enterocyte effacement conserved among diverse enterobacterial pathogens. Proc Natl Acad Sci USA 1995; 92: 1664-1668.

33. Jarvis $\mathrm{KG}$, Girón JA, Jerse AE, McDaniel TK, Donnenberg MS, Kaper JB. Enteropathogenic Escherichia coli contains a putative type III secretion system necessary for the export of proteins involved in attaching and effacing lesion formation. Proc Natl Acad Sci USA 1995; 92: 7996-8000.

34. Rocque WJ, Coughlin RT, McGroarty EJ. Lipopolysaccharide tightly bound to porin monomers and trimers from Escherichia coli K-12. J Bacteriol 1987; 169: 4003-4010.

35. Wu M-C, Heath EC. Isolation and characterization of lipopolysaccharide protein from Escherichia coli. Proc Natl Acad Sci USA 1973; 70: 2572-2576.

36. Bilge SS, Varu JC, Potter K, Dowell SF, Tarr PI. Escherichia coli $\mathrm{O} 157: \mathrm{H} 7$ lipopolysaccharide mutants are hyperadherent, abstr. B-2. Abstracts of the 95th Annual Meeting of the American Society for Microbiology, Washington, DC, USA. 1995: 166 